\title{
Establishing the Role of Unlinked Total Elbow Arthroplasty in Low Demand Patients: A Long-Term Follow-up Study
}

\section{Artroplastia Total do Cotovelo Não Restritiva em Doentes de Baixa Demanda Física: Um Estudo de Seguimento de Médio a Longo Prazo}

Sara MACHADO $\triangle^{1,2}$, Isabel Almeida PINTO ${ }^{1}$, Rui PINTO ${ }^{1}$, Paulo Ribeiro de OLIVEIRA ${ }^{1}$

Acta Med Port 2016 Jun;29(6):367-372 - http://dx.doi.org/10.20344/amp.6064

ABSTRACT

Introduction: Experience with total elbow arthroplasty is scarce in most centers. It seems to have a significant rate of associated complications. Most studies are based on non-validated outcome measures and short-term results.

Material and Methods: We selected patients undergoing unlinked total elbow arthroplasty, with a resultant sample of thirteen cases, with a mean postoperative follow-up of 72 months. We applied the Mayo Elbow Score and all patients underwent an X-ray study, prior to surgery and during the follow-up period.

Results: All patients have a systemic inflammatory condition. The mean Mayo score increased from 43 points preoperatively to 70 and 80 points at the intermediate follow-up period (with a mean of 15 months after the operation) and at the time of the latest follow-up evaluation (with a mean of 72 months after the operation). There was an increase in range of motion in all cases. There was one case of mechanical failure and two cases of transient ulnar neuropathy.

Discussion: Elbow dysfunction causes great loss in patient's quality of life, incapacitating them for the simplest activities. Small improvements in range of motion and pain relief result in significant changes in the patient's functional ability. There is a demand to clarify the performance of total elbow arthroplasty in selected patient groups in order to throw more light on the relative roles of the available implants.

Conclusions: The results obtained in this study seem to confirm the long-term benefit of the unlinked arthroplasty in severe joint dysfunction in patients with low physical demand, particularly in rheumatoid arthritis, a common and limiting condition in our population.

Keywords: Arthroplasty, Replacement; Elbow Joint; Joint Prosthesis; Treatment Outcome.

\section{RESUMO}

Introdução: Na maioria dos centros a experiência com a artroplastia total do cotovelo é escassa, parecendo existir taxas significativas de complicações associadas. A maioria dos estudos realizados até à data baseia-se em scores não validades e em resultados a curto prazo.

Material e Métodos: Selecionamos doentes submetidos a artroplastia total do cotovelo, com uma amostra resultante de treze artroplastias, recorrendo ao mesmo tipo de prótese - não restritiva, de baixa demanda física, com seguimento médio pós-operatório de 72 meses. Aplicamos o score de Mayo e efetuamos um estudo radiográfico pré operatoriamente e durante o período de seguimento. Resultados: Todos os doentes possuem uma patologia inflamatória sistémica. O score de Mayo médio evoluiu de 43 pontos préoperatoriamente para 70 e 80 pontos no período de seguimento intermédio (em média 15 meses após a artroplastia) e no momento da última avaliação (em média 72 meses após a artroplastia) respetivamente. Registamos um aumento na amplitude de movimentos em todos os casos. Registamos um caso de falência mecânica e dois de neuropatia cubital transitória.

Discussão: A disfunção do cotovelo acarreta grande perda na qualidade de vida do doente, incapacitando-o para atividades simples da sua vida diária. Pequenas melhorias na amplitude de movimentos e alívio da dor resultam em alterações significativas na capacidade funcional. Este estude surgiu da necessidade de esclarecer o resultado dos implantes existentes nos diferentes grupos populacionais.

Conclusão: Bons resultados no alívio da dor e na capacidade funcional são obtidos a longo prazo com a artroplastia total do cotovelo não restritiva, que assim demonstra ser uma excelente opção terapêutica nos doentes de baixa demanda física com artropatia do cotovelo, nomeadamente na artrite reumatoide, condição comum e limitante na nossa população.

Palavras-chave: Articulação do Cotovelo; Artroplastia de Substituição; Prótese Articular; Resultado do Tratamento.

\section{INTRODUCTION}

Total elbow arthroplasty (TEA) is a therapeutic option in patients with important joint destruction. ${ }^{1}$ Indications for TEA include: inflammatory arthropathies (the classic indication), posttraumatic osteoarthritis, tumor resection, distal humerus acute fractures and nonunions. The available implants can be grouped into linked (with the humeral and ulnar components physically connected) and unlinked. The former group can be sub-divided further depending on whether there is varus-valgus play between the humeral and ulnar components (sloppy hinge) or there is no play (fixed hinge). Currently, most linked implants are semiconstrained: their linking mechanism behaves as a sloppy hinge. Semiconstrained implants are believed to transmit less stress to the implant-cement-bone interface which can result in more reliable long-term fixation. Some implants can also incorporate a replacement for the radial

\footnotetext{
1. Departamento de Ortopedia e Traumatologia. Centro Hospitalar de São João. Porto. Portugal.

2. Departamento de Anatomia. Faculdade de Medicina da Universidade de Porto. Portugal.

$\square$ Autor correspondente: Sara Machado. saraguimaraes83@hotmail.com

Recebido: 07 de dezembro de 2014 - Aceite: 28 de Setembro de 2015 | Copyright @ Ordem dos Médicos 2016
} 
head..$^{2-8}$ Unlinked implants are an option for patients with relatively preserved bone stock and ligaments. These may be associated with a higher risk of instability and decreased elbow extension. Linked implants may prevent instability, allowing replacement for a wider spectrum of indications. However these implants raise the concern of increased contact pressures on the already thin polyethylene. Experience with TEA is still scarce in most centers and results reported for TEA are not as good as those for hip and knee replacement, with higher rate of associated complications such as infection, mechanical failure, triceps weakness or neuropathies, although the published number of studies have tended to be comparatively small. ${ }^{9}$ Revision rates can reach $15 \%$ at some mid-term studies. ${ }^{10}$ Most studies are primarily based on short-term results, and currently there is no consensus on the best implant to use in different clinical settings. ${ }^{10}$ Comparative studies between the different available implants seem to use non validated outcome measures what makes comparison difficult and results potentially unreliable. ${ }^{11-16}$ There 's a demand to clarify the long-term performance of TEA in selected patient groups in order to throw more light on the relative roles of the available implants.

Our aims were: 1) to establish if the benefits obtained with total elbow arthroplasty reported in the few short-term studies existing in the literature are confirmed in our sample of patients, and if those results remain in a long term followup; 2) to establish this benefit in patients suffering from a systemic inflammatory disorder, which are the majority of patients with indication for elbow arthroplasty currently; and 3 ) to determine the role of unlinked implants, referred to in some literature as functionally inferior to semi-restrictive implants.

\section{MATERIAL AND METHODS \\ Population}

We selected all low physical demand patients undergoing unlinked TEA in the same institution, obtaining a sample of thirteen elbows in eleven patiens. Elbow stability tests were performed. Patients with a positive valgus and/or varus stress test were excluded. Inflammatory conditions, such as rheumatoid arthritis, represent the main indication for elbow arthroplasty. The patients with more severe involvement may experience great improvements in pain and function. The polyarticular involvement of these conditions may limit the overall activity level of these patients, with a low rate of wear and loosening. We allways need to check if there is enough bone stock and ligamentous integrity to allow the use of unlinked implants.

\section{Implant Type}

The implant and the operative techniques for the arthroplasty did not differ among the thirteen cases. The used implant was the KUDU prosthesis. A straight posterior midline skin incision was made. Ulnar nerve was individualized. A triangular-shaped flap with a distal base was raised in the triceps tendon. The radial head was always excised. Distraction of the humerus from the ulna, which was necessary for insertion of the ulnar component, was obtained by careful cleaning of all of the soft tissues from the inside of the collateral ligaments. Postoperatively, the elbow was immobilized in $90^{\circ}$ of flexion in a posterior splint for one week. Active and active-assisted motion exercises were then begun. In this kind of implant congruency depends on the adequate position of each component, ligamentous integrity, and the dynamic stabilizing effect of the musculature. These implants provide a more or less anatomic resurfacing of the distal humerus and proximal ulna. A KUDU prosthesis is represented in the Fig. 1.

\section{Study Type}

The selected patients were followed prospectively for a mean postoperative follow-up of 72 months (Table 1). We evaluated the Mayo Elbow Performance score (a score that assesses pain, range of motion, stability, and ability to perform daily activities) preoperatively, at the intermediate follow-up period (with a mean of 15 months after the operation) and at the time of the latest follow-up evaluation (60 to 116 months after the operation). The arc of motion was assessed with patient supine with the humerus close to the body, the shoulder in the neutral position, and the forearm supinated. A bolster was placed under the distal humerus. A goniometer was used with the fulcrum centered over the lateral epicondyle, the stationary arm aligned with the long axis of the humerus, using the acromion

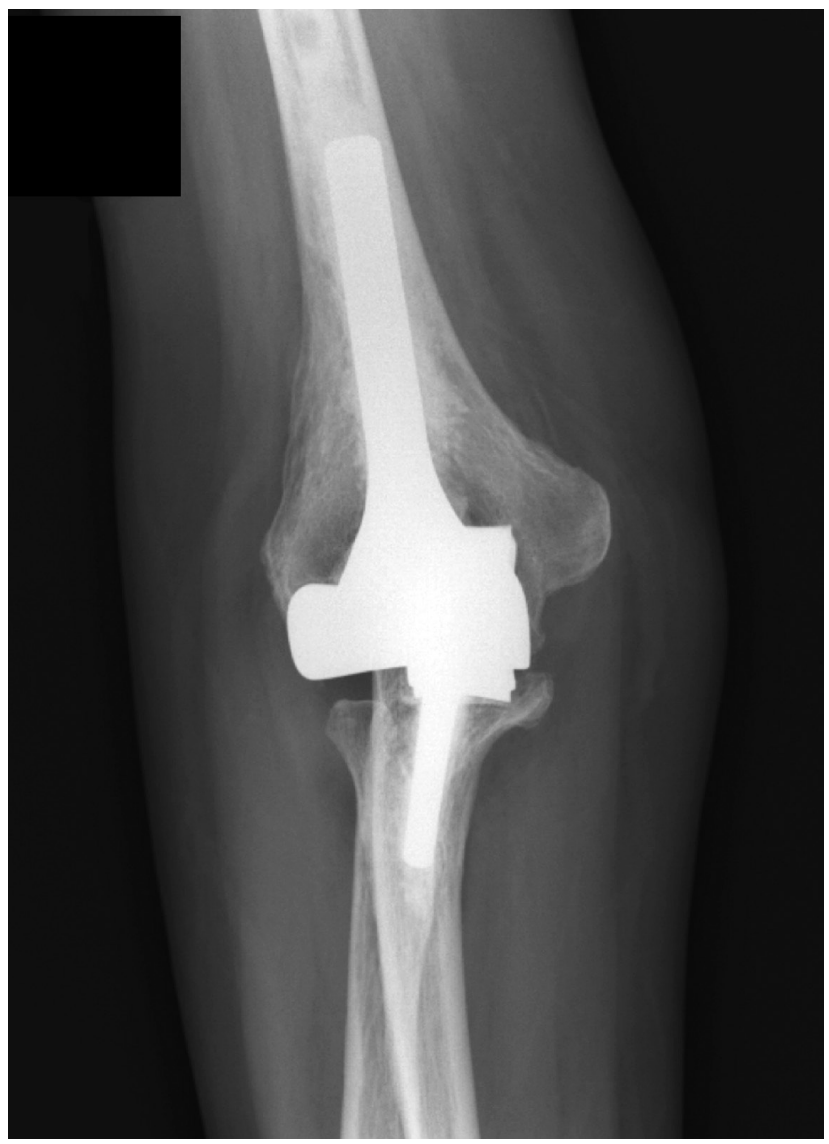

Figure 1 - Radiographic follow-up 
Table 1 - Demographic data

\begin{tabular}{lc} 
No. of elbows/ no. of patients & $13 / 11$ \\
Mean age at time of surgery (years) & 53 \\
Gender M/F (no. of patients) & $0 / 11$ \\
Arthritis etiology (\%) & \\
$\quad$ Rheumatoid arthritis & $80 \%$ \\
$\quad$ Psoriatic arthritis & $20 \%$ \\
Mean duration of arthritis (years) & 12 \\
Mean duration of elbow symptoms (years) & 7 \\
Involved side R/L (no. of elbows) & $7 / 6$ \\
Mean follow-up period (months) & 72 \\
\hline
\end{tabular}

process as the proximal landmark and the movement arm aligned with the long axis of the radius, using the styloid process as the distal landmark. Implant complications (loosening, instability, infection, radiolucencies, failure of repair of the triceps, ulnar nerve lesions and overall complications) were also assessed. There is no universal definition of loosening. ${ }^{17}$ We considered the implant to be 'loose' when there is a migration of a component, a complete radiolucency of at least $2 \mathrm{~mm}$ or the presence of radiolucencies and symptomatic loosening. Components found to be loose at revision were also categorised as loose regardless of the radiographic findings. A second, broader consideration of radiolucencies was established to include all complete radiolucencies of at least $1 \mathrm{~mm}$, all those which showed progression and those components which had previously defined as being loose. For the statistical analysis we used the IBM SPSS Statistics $20^{\circledR}$ software.
The population normality was assessed by the Shapiro-Wilk test. Using descriptive statistics, we determined the mean value, standard deviation, median, minimum and maximum and the frequency of certain categories.

\section{RESULTS}

Preoperative age, etiology, duration of disease and elbow symptoms, involved side and follow-up periods are shown in Table 1.

All patients suffer from inflammatory arthritis, rheumatoid arthritis in $80 \%$ and psoriatic arthritis in the remaining $20 \%$. All are female, with an average age of $53 \pm 19$ years at the time of surgery. The mean duration of inflammatory disease and elbow symptoms was twelve and seven years, respectively.

\section{Clinical Assessment}

The Mayo score prior to surgery was poor in all patients (mean 43 points). There was a gradual improvement in this score after surgery, with a mean score of 70 and 80 points at the intermediate follow-up period and at the time of the latest follow-up evaluation, primarily due to the influence on pain reduction and improvement in the ability to perform daily activities (Fig. 2).

There was an increase in range of motion in all cases with a mean range of $100^{\circ}$ (Table 2). According to the score used, the results are excellent (score greater than 90) in 50 $\%$ of patients, good (score $75-89$ ) in $30 \%$, fair (score $60-74$ ) in $10 \%$ and poor (score below 60 ) in 10\% (see Fig. 3 ).

\section{Radiographic Assessment}

The rate of radiolucencies about the humeral component

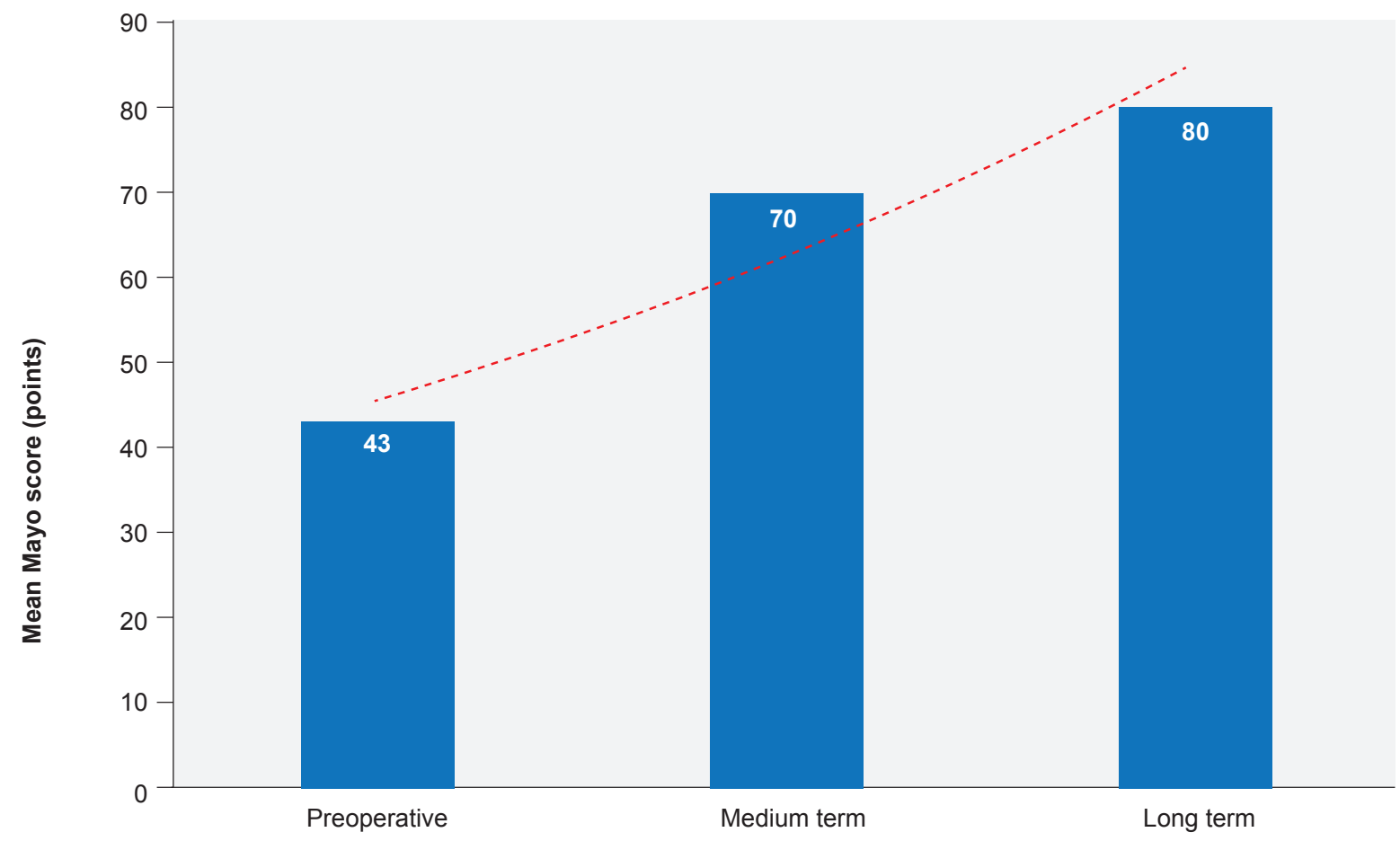

Figure 2 - Mayo score evolution over time 
Table 2 - Clinical assessment

\begin{tabular}{|c|c|c|c|}
\hline & Preop. & Mid term & Long term \\
\hline \multicolumn{4}{|l|}{ Pain (no. of elbows) } \\
\hline None & 0 & 7 & 9 \\
\hline Mild & 1 & 6 & 3 \\
\hline Moderate & 10 & 0 & 0 \\
\hline Severe & 2 & 0 & 0 \\
\hline \multicolumn{4}{|c|}{ Mean range of motion (degrees) } \\
\hline Arc $>100$ & 1 & 3 & 3 \\
\hline Arc $50-100$ & 12 & 10 & 10 \\
\hline Arc $<50$ & 0 & 0 & 0 \\
\hline \multicolumn{4}{|c|}{ Stability (no. of elbows) } \\
\hline Stable & 12 & 13 & 13 \\
\hline Moderately stable & 1 & 0 & 0 \\
\hline Grossly unstable & 0 & 0 & 0 \\
\hline \multicolumn{4}{|c|}{ Daily function (no. of elbows) } \\
\hline 25 points & 0 & 0 & 1 \\
\hline 20 points & 0 & 4 & 4 \\
\hline 15 points & 1 & 8 & 7 \\
\hline 10 points & 10 & 0 & 0 \\
\hline 5 points & 2 & 1 & 1 \\
\hline
\end{tabular}

at mid-term follow-up was $30 \%$. This rate increased to $50 \%$ at long-term follow-up.

Two ulnar components had a radiolucent line at the mid and long term points. The implant loss occurred in only one case. (Fig. 4)

\section{Complications}

In one patient superficial infection of the wound was observed. Two cases had symptoms of ulnar neuropathy after the operation. These symptoms gradually resolved in both. There was one case of mechanical failure, nineteen months after placement. No other complications have been described, including instability or peri-prosthetic fractures. $90 \%$ of patients showed satisfaction with the treatment.

\section{DISCUSSION}

The significant elbow functional limitation causes great loss in patients quality of life. Small improvements in range of motion and pain relief result in significant changes in the patient's functional ability. TEA is a therapeutic option for patients with important elbow destruction. Unlinked implants that allow less bone resection may be important in a revision arthroplasty, especially because we deal with patients with a life expectancy still high (mean age of our sample was 53 years). However, there is some concern about a higher instability, flexion contracture and long term results associated with these implants. ${ }^{18}$ Moreover the majority of patients requiring a TEA for elbow destruction are carriers of a systemic inflammatory disease such as rheumatoid arthritis, a common and extremely limiting condition in a population group still young. In rheumatoid elbow arthritis there are multiple cytokines with osteoclastogenic activity. Even with the use potent anti-inflammatory drugs, there are only slight signs of repair. ${ }^{18-21}$ Since these patients maintain their systemic inflammatory condition after surgery, may be questioned if the results remain satisfactory over time. There are short-term studies in the literature showing good results but there's a lack of information on the long-term results. Also the outcomes were frequently presented using non-validated scoring systems; this is not surprising in a field where validation of such scores has only recently been published. Our study confirm the benefit of the unlinked

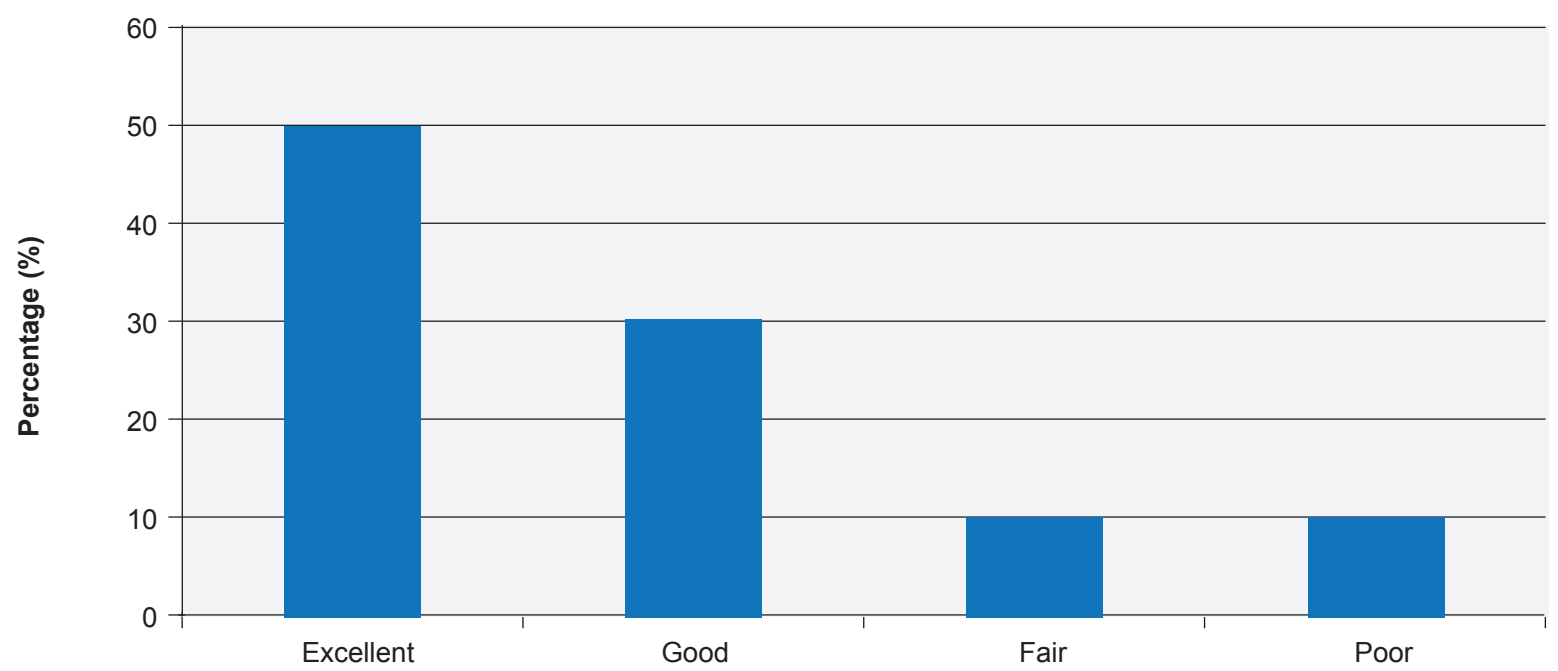

Mayo score classification

Figure 3 - Actual mean grade of total Mayo score 


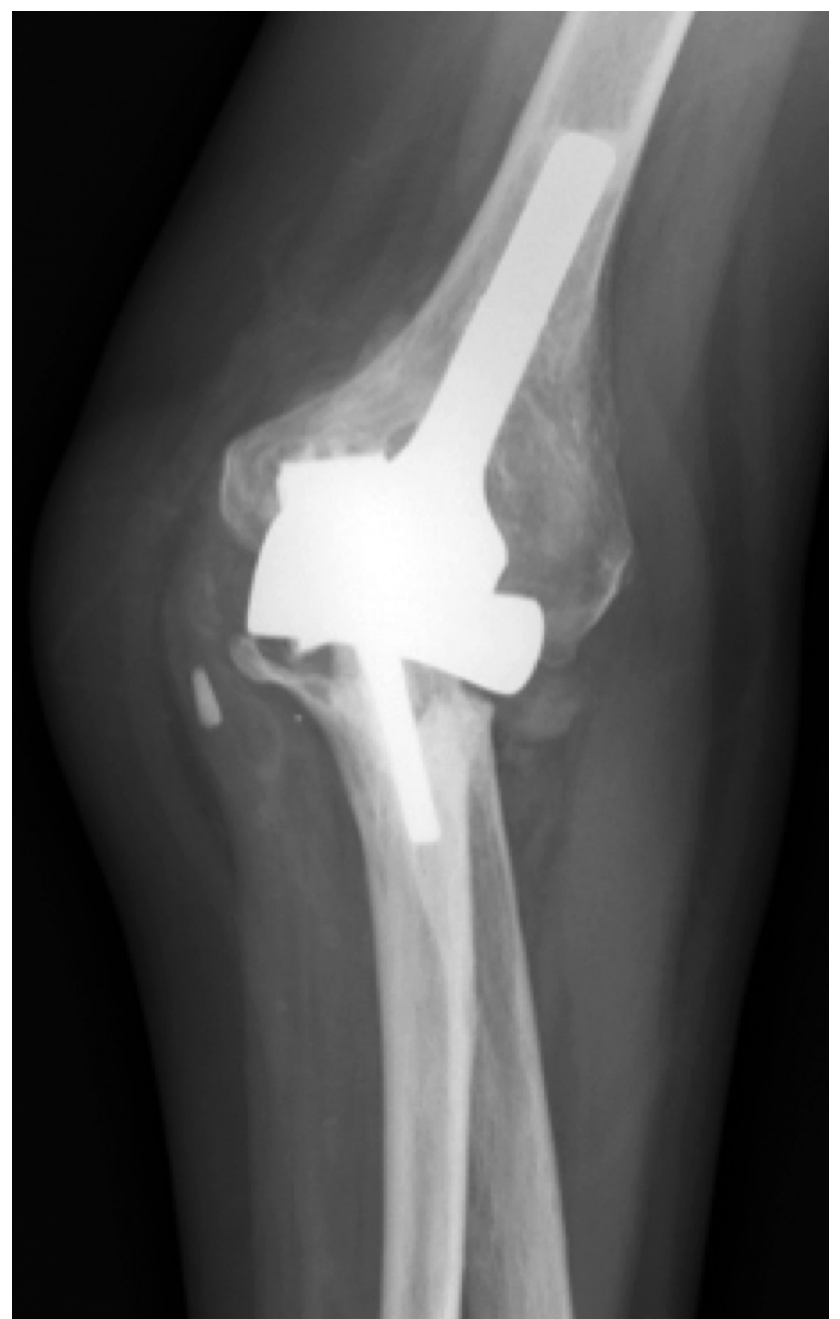

Figure 4 - Implant loss

implants in low physical demand patients with severe elbow dysfunction, particularly for pain relief and ability to perform daily activities, improving their quality of life, reaching up very good to excellent results in most cases. And most importantly, our study showed that these results are maintained in a long-term period, with good implant survival and low complication rates. In terms of function, according to the available literature, the range of movement achieved with a sloppy hinge linked implant appeared to be better than that with unlinked implants, perhaps because the bone can be shortened to improve movement without risking instability of the prosthesis. This may explain a greater improvement in fixed flexion deformity seen with the Coonrad-Morrey elbow in comparison to the Kudo devices. However, our patiens showed an increase in range of motion in all cases with a mean range of $100^{\circ} .22-26$ Furthermore, we do not observe greater instability or flexion contracture associated with these implants. One of the reasons given to support the use of an unlinked over a linked device is that by relying on soft-tissue balance the risk of loosening is lower. However, the literature reviewed here suggests that sloppy hinge devices may have lower rates of loosening than unlinked devices. The most common mode of failure for unlinked devices was aseptic loosening. However, given the lack of a universally accepted definition of radiographic loosening this should be interpreted with caution. While the reported rates of loosening for linked devices are lower than those for unlinked implants, the former have much higher rates of progressive radiolucencies which may herald loosening in the future. In a long-term follow-up we registed only one case of loosening, which represent $7 \%$ of cases. Inflammatory arthropathies represent the indication of elbow arthroplasty in all patients. Those patients with more severe involvement experience great improvements in pain and function. The polyarticular nature of these conditions may limit the overall activity level of these patients, with a low rate of wear and loosening. Regarding the potential study limitations, despite these favorable results in the present series of TEA, future studies are needed to verify the clinical efficacy of the implants with larger series of patients and in others clinical settings like posttraumatic osteoarthritis and others.

\section{CONCLUSION}

Unlinked implants showed good long term results in patients with a systemic inflammatory pathology, that corresponds to the majority of patients with indication for arthroplasty realization currently.

Benefits are particularly evident for pain relief and ability to perform daily activities, with very good to excellent results in most cases.

There was no greater instability or flexion contracture associated with these implants.

\section{OBSERVATIONS}

Part of the results of this paper were oraly presented and discussed during the $15^{\text {th }}$ Congress of European Federation of National Associations of Orthopaedics and Traumatology (EFORT), held in London between 4 and 6, June 2014.

\section{PROTECTION OF HUMANS AND ANIMALS}

The authors declare that the procedures were followed according to the regulations established by the Clinical Research and Ethics Committee and to the Helsinki Declaration of the World Medical Association.

\section{DATA CONFIDENTIALITY}

The authors declare having followed the protocols in use at their working center regarding patient's data publication.

\section{CONFLICTS OF INTEREST}

The authors declare that there are no conflicts of interest.

\section{FUNDING SOURCES}

No subsidies or grants contributed to this work. 


\section{REFERENCES}

1. Mora-Navarro N, Sánchez-Stelo J. Elbow replacement. Rev Esp Cir Ortop Traumatol. 2012;56:413-20.

2. Morrey BF, Adams RA. Semiconstrained arthroplasty for the treatment of rheumatoid arthritis of the elbow. J Bone Joint Surg Am. 1992;74:479 90.

3. Kudo H, Iwano K. Total elbow arthroplasty with a non-constrained surfacereplacement prosthesis in patients who have rheumatoid arthritis. A long- term follow-up study. J Bone Joint Surg Am. 1990;72:355-62.

4. Ruth JT, Wilde AH. Capitellocondylar total elbow replacement. A longterm follow-up study. J Bone Joint Surg Am. 1992;74:95-100.

5. Kudo H, Iwano K, Nishino J. Total elbow arthroplasty with use of a noncon- strained humeral component inserted without cement in patients who have rheumatoid arthritis. J Bone Joint Surg Am. 1999;81:1268-80.

6. Little CP, Graham AJ, Carr AJ: Total elbow arthroplasty: a systematic review of the literature in the English language until the end of 2003. J Bone Joint Surg Br. 2005;87:437-44.

7. Lowe LW, Miller AJ, Allum RL, Higginson DW. The development of an unconstrained elbow arthroplasty: a clinical review. J Bone Joint Surg [Br]. 1984;66:243-7.

8. Rosenberg GM, Turner RH. Nonconstrained total elbow arthroplasty. Clin Orthop. 1984;187:154-62.

9. Rahme H, Jacobsen MB, Salomonsson B. The Swedish Elbow Arthroplasty Register and the Swedish Shoulder Arthroplasty Register: two new Swedish arthroplasty registers. Acta Orthop Scand. 2001;72:107-12.

10. Jenkins PJ, Watts AC, Norwood T, Duckworth AD, Rymaszewski LA, McEachan JE. Total elbow strains: outcome of 1,146 arthroplasties from the Scottish Arthroplasty Project. Acta Orthop. 2013;84:119-23.

11. Morrey BF, Bryan RS, Dobyns JH, Linscheid RL. Total elbow arthroplasty. A five-year experience at the Mayo Clinic. J Bone Joint Surg Am. 1981;63:1050-63.

12. Risung F. The Norway elbow replacement. Design, technique and results after nine years. J Bone Joint Surg Br. 1997;79:394-402.

13. Mackay DC, Hudson B, Williams JR. Which primary shoulder and elbow replacement?: a review of the results of prostheses available in the UK. Ann R Coll Surg Engl 2001;83:258-65.
14. Kraay MJ, Figgie MP, Inglis AE, Wolfe SW, Ranawat CS. Primary semicon-strained total elbow arthroplasty: survival analysis of 113 consecutive cases. J Bone Joint Surg [Br]. 1994;76:636-40.

15. Davis RF, Weiland AJ, Hungerford DS, Moore JR, Volenec-Dowling S. Non-constrained total elbow arthroplasty. Clin Orthop. 1982;171:15660.

16. Wright TW, Wong AM, Jaffe R. Functional outcome comparison of semicon-strained and unconstrained total elbow arthroplasties. J Shoulder Elbow Surg. 2000;9:524-31.

17. Craik JD, Laffer CH, Richards SW, Walsh SP, Evans SL. Distal humerus cortical strains following total elbow arthroplasty. Proc Inst Mech Eng H. 2013;227:120-8.

18. Figgie HE 3rd, Inglis AE, Ranawat CS, Rosenberg GM. Results of total elbow arthroplasty as a salvage procedure for failed elbow reconstructive operations. Clin Orthop. 1987;219:185-93.

19. Arboleya L, Castañeda S. Osteoimmunology: the study of the relationship between the imune system and bone tissue. Reumatol Clin. 2013;9:303-15.

20. Arron JR, Choi Y. Bone versus immune system. Nature. 2000;408:535-6

21. Deal C. Bone loss in RA: systemic, periarticular and focal. Curr Rheumatol Rep. 2012;14:231-7.

22. Barlow JD, Morrey BF, O'Driscoll SW, Steinmann SP, Sanchez-Sotelo J. Activities after total elbow arthroplasty. J Shoulder Elbow Surg. 2013;22:787-91.

23. Szyluk K, Widuchowski W, Jasiński A, Koczy B, Widuchowski J. Comparison of short- to medium-term results of Coonrad-Morrey elbow replacement in patients with rheumatoid arthritis versus patients after elbow injuries. Med Sci Monit. 2013;19:18-27.

24. Kaback LA, Green A, Blaine TA. Elbow arthritis and total elbow replacement. Med Health R I. 2012;95:110-2, 116.

25. Maheshwari R, Vaziri S, Helm RH. Total elbow replacement with the Coonrad-Morrey prosthesis: our medium to long-term results. Ann $\mathrm{R}$ Coll Surg Engl. 2012; 94:189-92.

26. Lubiatowski P, Olczak I, Lisiewicz E, Bręborowicz M, Długosz J, Redman $\mathrm{M}$, et al. Clinical and functional evaluation of patients after total elbow arthroplasty. Pol Orthop Traumatol. 2013;78:53-8. 